\title{
Behold the glory of the King: The chiastic structures of Matthew 21-25
}

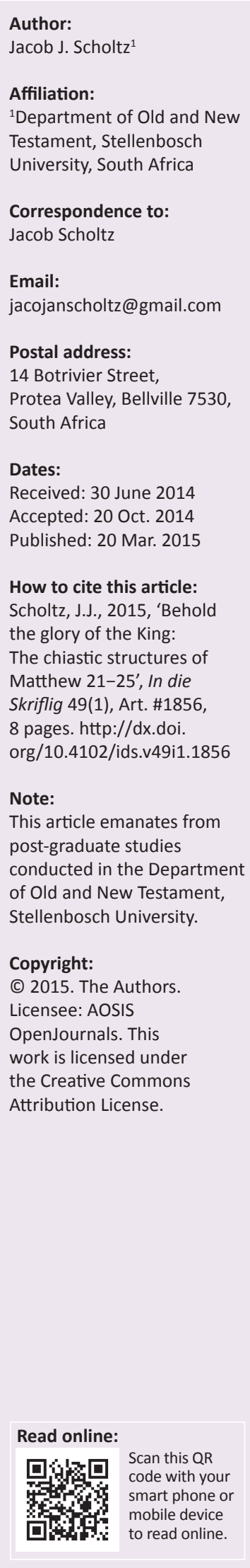

The Olivet Discourse is complex and difficult to interpret, but crucial to any preaching about eschatology. By identifying two chiastic structures that mirror each other, namely in Matthew 21:1-23:39 and 24:1-25:46, the relation and correspondence of the parts to each other and to the whole may be identified. Whereas the centre of the chiastic structure of Matthew 21:1-23:39 emphasises the authority and identity of Jesus Christ, the Lord and Son of David, the centre of the chiastic structure of 24:1-25:46 focuses on the sign and coming of the Son of Man. Matthew 21:1-25:46 could be a major literary unit that emphasises the King's entrance into, rejection of and exit from the temple and Jerusalem during his first coming, juxtaposed with the sign and coming of the Son of Man to Jerusalem in glory. Until then, the Lord expects his followers to watch, to be ready and prepared as they labour faithfully for him in these last days.

Kyk die heerlikheid van die Koning: Die chiastiese strukture van Matteus 21-25. Die Olyfberg-diskoers is kompleks en moeilik om te interpreteer, dog onontbeerlik vir enige prediking oor die eskatologie. Deur die eiening van twee chiastiese strukture wat mekaar weerspieël, naamlik in Matteus 21:1-23:39 en 24:1-25:46, kan die verhouding en ooreenkomste van die dele tot mekaar en die geheel geïdentifiseer word. Waar die middelpunt van die chiastiese struktuur in Matteus 21:1-23:39 die gesag en identiteit van Jesus Christus, die Here en Seun van Dawid, beklemtoon, fokus die middelpunt van die chiastiese struktuur in 24:1-25:46 op die teken en koms van die Seun van die Mens. Matteus 21:1-25:46 sou 'n belangrike literêre eenheid kon wees wat die Koning se ingang na, verwerping en agterlaat van die tempel en Jerusalem tydens sy eerste koms beklemtoon teenoor die teken en koms van die Seun van die Mens na Jerusalem in heerlikheid. Tot dan verwag die Here van sy volgelinge om te waak, om gereed en voorbereid te wees terwyl hulle getrou in hierdie laaste dae vir Hom arbei.

\section{Introduction}

The interpretation of the Olivet Discourse is a notoriously complex task, especially in terms of analysing its structure. Thus, Carson (1995:491; cf. Tasker 1971:223; Hagner 1995:684) states that the 'most difficult interpretative questions concern the structure of the discourse - how the parts relate to each other, to the initial questions of the disciples, and to the whole'. Whereas a chiastic structure has been proposed for Matthew 21:1-23:39 previously (Scholtz 2014a), this present article explores whether 21:1-25:46 $6^{1}$ could be a major literary unit containing two chiastic structures that mirror each other, namely 21:1-23:39 and 24:1-25:46. The purpose of this article is firstly, to briefly identify some relevant theological positions and presuppositions; secondly, to propose chiastic structures for 21:1-23:39 and 24:1-25:46; thirdly, to evaluate the proposal and fourthly, to suggest a possible interpretation of 21:1-25:46 using the structural features of this literary unit.

\section{Identification of theological positions}

The complexity of the Olivet Discourse has given rise to various schools of interpretation for Matthew 24-25. Whereas preterists connect 24:4-35 exclusively to the fall of Jerusalem in AD 70 (Tasker 1971:223-228; France 2007:890-896), futurists argue that this passage refers primarily to the seven-year Tribulation Period immediately preceding Christ's return (Toussaint 1980:266-292; Pettegrew 2002:173-190). Turner (2008:566-567; cf. Hagner 1995:685), a proponent of the preteristfuturist view, understands $24-25$ as 'addressing both the historical destruction of Jerusalem and the yet-future coming of Jesus'. Turner (1989:3-5) also identifies a traditional and revised preteristfuturist view. The traditional preterist-futurist view holds that 24:4-14 deals with the present age, 24:15-28 with the fall of Jerusalem, but with some references to the end of the age, 24:29-31 with the $\pi \alpha \rho o v \sigma i \alpha$, and 24:32-41 with the certainty of the fulfilment of prophecy. According to the 
revised preterist-futurist view (cf. Carson 1995:488-495), clear breaks are identified in the discourse, which alternatively describes the events of AD 70 (specifically 24:15-21) and the end of this age. Even though many evangelical scholars take the preterist-futurist approach, dividing the first part of the Olivet Discourse between historical and eschatological events, Blaising (2012:138) warns that this may lead to 'structural incoherence'.

The present article is written from a pre-millennial perspective and, for the most part, follows the futurist view. In 12:32, the blasphemy against the Spirit will not be forgiven in this age or the age to come (cf. 13:39-40, 49-50; 24:3, 6, 14; 28:20). According to Price (1996:103; cf. Burrows 1955:7-8), the rabbis and Jews of the Inter-testamental period distinguished between this age

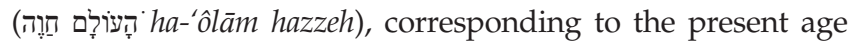
including the Tribulation Period, and the age to come (הָוֹרָם ha-'ôlam habbä'), the Messianic age. After the Messianic age is the eternal state (Price 1996:105). Burrows (1955:4) argues that the two ages will follow each other consecutively in time and Burge (2001:1195) affirms that in Scripture, time is presented as linear (or horizontal) and says both 'this age and the age to come will appear in the same historical plane'.

The Tribulation Period is understood as a seven-year period immediately preceding the return of Jesus Christ to the earth (Toussaint 1980:141). The Tribulation Period thus transitions this age into the age to come. According to Fruchtenbaum (2004:181), when the Scriptures refer to the actual phrase the Day of Jehovah or the Day of the Lord, it always refers to the seven-year Tribulation Period, but other non-negative references to that day or in that day may be used for both the Tribulation Period and the millennium.

A detailed defence of pre-millennialism falls outside the scope of this article, but Vlach (2012) supports a biblical case for pre-millennialism under three headings:

[1] Predictions of a coming reign of the Messiah over the nations on a restored earth after a time of worldwide tribulation [and judgement]. [2] Old Testament evidence of a period of time - an intermediate kingdom - that is distinct from both the present age and the eternal state. [3] Explicit prediction of an intermediate kingdom that is one thousand years long ( $\operatorname{Rev} 20: 1-10)$. (p. 227) 2

Referring to Isaiah 24-25, Daniel 12:1-3 and Zechariah 14, Vlach (2012:227-233) identifies a pattern of 'tribulation' or the 'Day of the Lord', followed by judgement and then the establishment of the kingdom of heaven - before connecting this pattern to the chronology of events according to Matthew 24-25, namely tribulation, cosmic signs, the return of Jesus, judgement and then inheriting the kingdom.

Does the futurist view adequately deal with the questions of the disciples and how the parts of the discourse relate to each other and to the whole (cf. Carson 1995:491)? According to some commentators (Toussaint 1980:267; Hagner 1995:688),

2.Referring to Isaiah 65:20 and Zechariah 14, Vlach (2012:237-240) identifies conditions that can apply to neither the present age nor the eternal state, but may rather apply to an intermediate kingdom period, that is, the millennium.
Matthew does not record Jesus' answer as to 'when' the temple will be destroyed (24:2-3a). But why, then, is this question recorded in Matthew (cf. Carson 1995:494-495; Turner 1989:5-7)?

Jesus had just said, 'See! Your house is left to you desolate; for I say to you, you shall see Me no more till you say, "Blessed is He who comes in the Name of the Lord!"' (23:38-39). Jesus often spoke about 'this generation' when referring to his contemporaries $(11: 16 ; 12: 39,41,42$, $45 ; 16: 4 ; 23: 36)$. Would 'this generation' in Israel be the Jewish generation who would call on Christ to return? The answer is a firm 'no', since 'this generation' had already rejected Christ (11:16; 12:23-45: 23:36). A future generation of believing Jews will accept the Messiahship of Christ. Allison (1983:77) argues that 23:39 should be understood as a conditional prophecy: ' $[T]$ he date of redemption is contingent upon Israel's acceptance of the person and work of Jesus.' Fruchtenbaum (2004) affirms what Allison (1983:78) describes as 'conditional eschatology':

Jesus will not come back to the earth until the Jews and the Jewish leaders ask Him to come back. For just as the Jewish leaders once led the nation to the rejection of the Messiahship of Jesus, they must some day lead the nation to the acceptance of the Messiahship of Jesus. (p. 307)

Carson (1995:495; cf. Hagner 1995:688; Turner 2008:569) rightly points out that 'the disciples think of Jerusalem's destruction and the eschatological end as a single complex web of events'. The disciples' two questions, however, combine events that appear, from a temporal perspective, to be mutually exclusive (cf. 24:3). Because 'this generation' blasphemed the Holy Spirit and thereby committed the unpardonable sin (12:24-32), the establishment of the kingdom in terms of the Davidic Covenant was postponed (Toussaint 1980:170; Fruchtenbaum 2004:664-665). This postponed Davidic kingdom could not again come near or be offered to another Jewish generation until 'this generation' was judged (12:23-32; cf. Scholtz 2014b:5). Consequently, the sign of Christ's coming and the end of the age could also not occur until 'this generation' was judged. With the benefit of hindsight, 'this generation' was judged in AD 70 when the temple was destroyed. Jesus therefore corrects the disciples' thinking that the destruction of the temple would immediately usher in the end of this age and Christ's return (Hagner 1995:688; Pettegrew 2002:180). Given the postponement of the establishment of the Davidic kingdom, Jesus also teaches a delay before the 'birth-pangs' begin (24:4-6; cf. 24:48; 25:5, 19; Pettegrew 2002:175; Fruchtenbaum 2004:624-625). Jesus' answer disentangles events that were confused in the disciples' thinking. These events cannot occur together (cf. Toussaint 1980:270), for 'this generation', living at the time of Christ's first advent, must first pass away before the sign of Christ's coming and the end of the age can possibly be near in time. Therefore, in the present article, 24:7-35 is not connected with the sign of Christ's coming and the end of the age as if these could have occurred from about AD 30 to 70 . Even though this article is primarily concerned with the chiastic structures of Matthew 21-25 and not with a synoptic comparison of the Olivet Discourse, it is worthwhile to note 
that the questions in Luke 21:7 are different from those in Matthew 24:3: the Lucan request is for a sign as to when the temple will be destroyed - not for the sign of Christ's coming and the end of the age (cf. Fruchtenbaum 2004:629-630).

\section{Chiastic structures proposed for Matthew 21:1-25:46}

Wilson (2004:69) convincingly argues that the theme of the coming King, first humbly and then in glory, forms an inclusio around Matthew 21-25 (21:1-17; 25:31-46). However, this major literary unit may contain two rhetorical units: 21:1-23:39, with the Messianic greeting as its inclusio (21:9; 23:39); and 24:1-25:46, with its inclusio being Jesus' exit from the temple and subsequent sitting on the Mount of Olives, juxtaposed with his return to the Mount of Olives and his sitting on the throne of his glory as King and Judge (24:1-3; 25:31-46; cf. Zch 14:4; Ac 1:9-12). Although part of a larger rhetorical unit (21:1-25:46), the change in setting from the temple to the Mount of Olives, the change in audience to only Christ's disciples, and the distinct (but related) themes all point to 24:1-25:46 as being a separate rhetorical unit (cf. Carson 1995:469; France 2007:768; Turner 2008:543-544). Whereas the species of rhetoric in 21:1-23:39 is the judicial issue of 'who has the right to proclaim judgment' (Grams 1991:51; cf. Wilson 2004:1), 24:1-25:46 seems to emphasise the actual exercise of such right to judge (cf. Morris 1992:593). Whilst 21:1-23:39 describes the judgement of the religious leaders and 'this generation' in Israel who rejected the Messiahship of Jesus at his first coming, in 24:1-25:46 the scope moves to a world-wide judgement of all nations at the end of the age who reject the coming King (cf. Blomberg 1992:351;
Wilson 2004:254-255). In terms of rhetorical arrangements, the following chiastic structures are proposed for 21:1-23:39 and 24:1-25:46 (see figure 1):

\section{Evaluation of the chiastic structures proposed for Matthew 21:1-25:46}

The nine criteria that Blomberg (1989) identifies for the evaluation of extended chiasmus were used to evaluate the chiastic structure for Matthew 21:1-23:39 (Scholtz 2014a) and are used to evaluate the proposed chiastic structure of 24:1-25:46:

(1) There must be a problem in perceiving the structure of the text in question, which more conventional outlines fail to resolve. ... (2) There must be clear examples of parallelism between the two 'halves' of the hypothesized chiasmus ... (3) Verbal (or grammatical) parallelism as well as conceptual (or structural) parallelism should characterize most if not all of the corresponding pairs of subdivisions. ... (4) The verbal parallelism should involve central or dominant imagery or terminology, not peripheral or trivial language. ... (5) Both verbal and conceptual parallelism should involve words and ideas not regularly found elsewhere within the proposed chiasmus. ... (6) Multiple sets of correspondences between passages opposite each other in the chiasmus as well as multiple members of the chiasmus itself are desirable. ... (7) The outline should divide the text at natural breaks which would be agreed upon even by those proposing very different structures to account for the whole. ... (8) The center of the chiasmus, which forms its climax, should be a passage worthy of that position in light of its theological or ethical significance. If its theme were in some way repeated in the first and last passages of the text, as is typical in chiasmus, the proposal would become that much more plausible. (9) Finally, ruptures in the outline should be avoided if at all possible. (pp. 5-8)

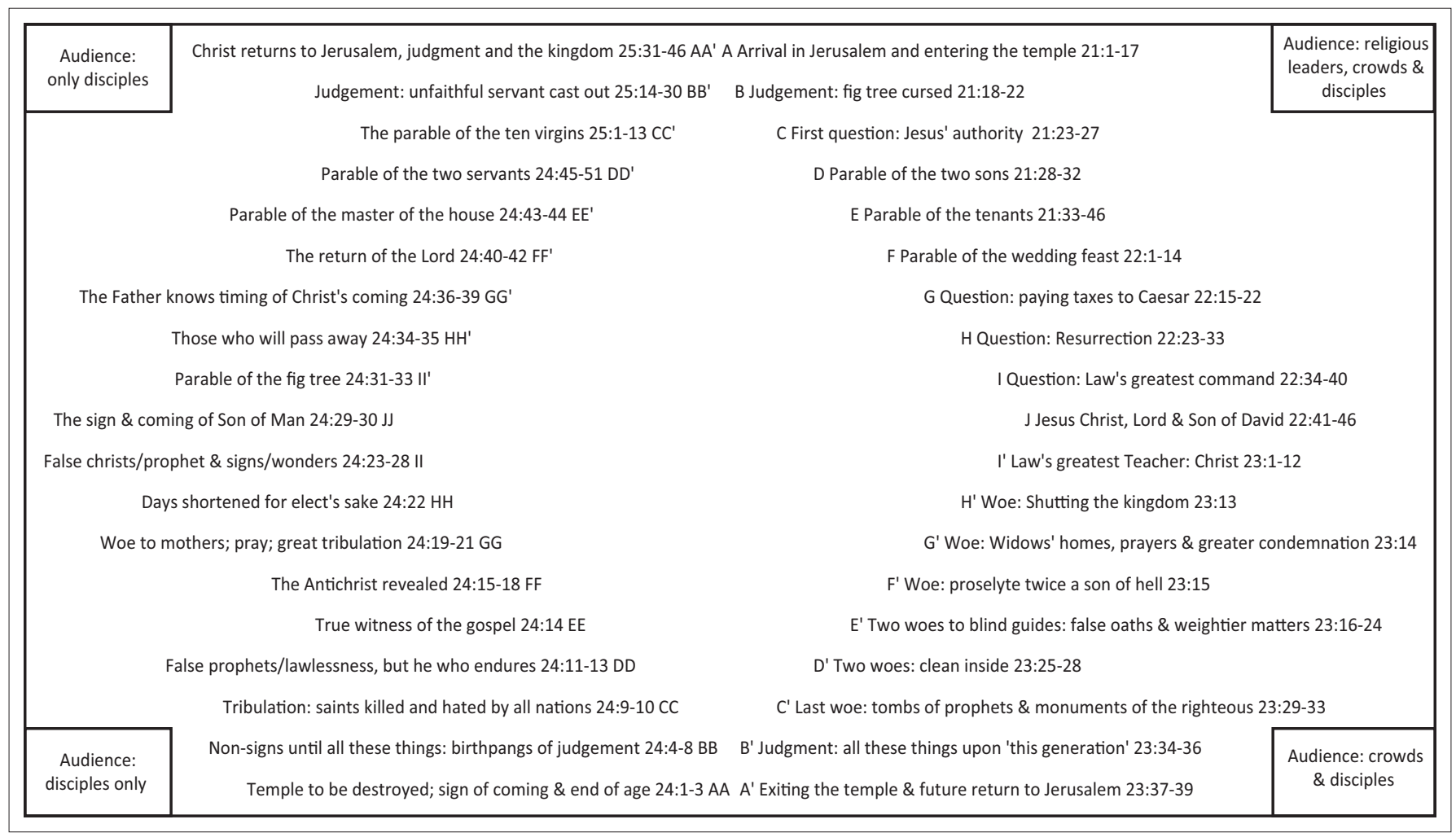

FIGURE 1: Proposed chiastic structures for Matthew 21:1-25:46. 
TABLE 1: Verbal and conceptual parallelism of Matthew 21:1-25:46.

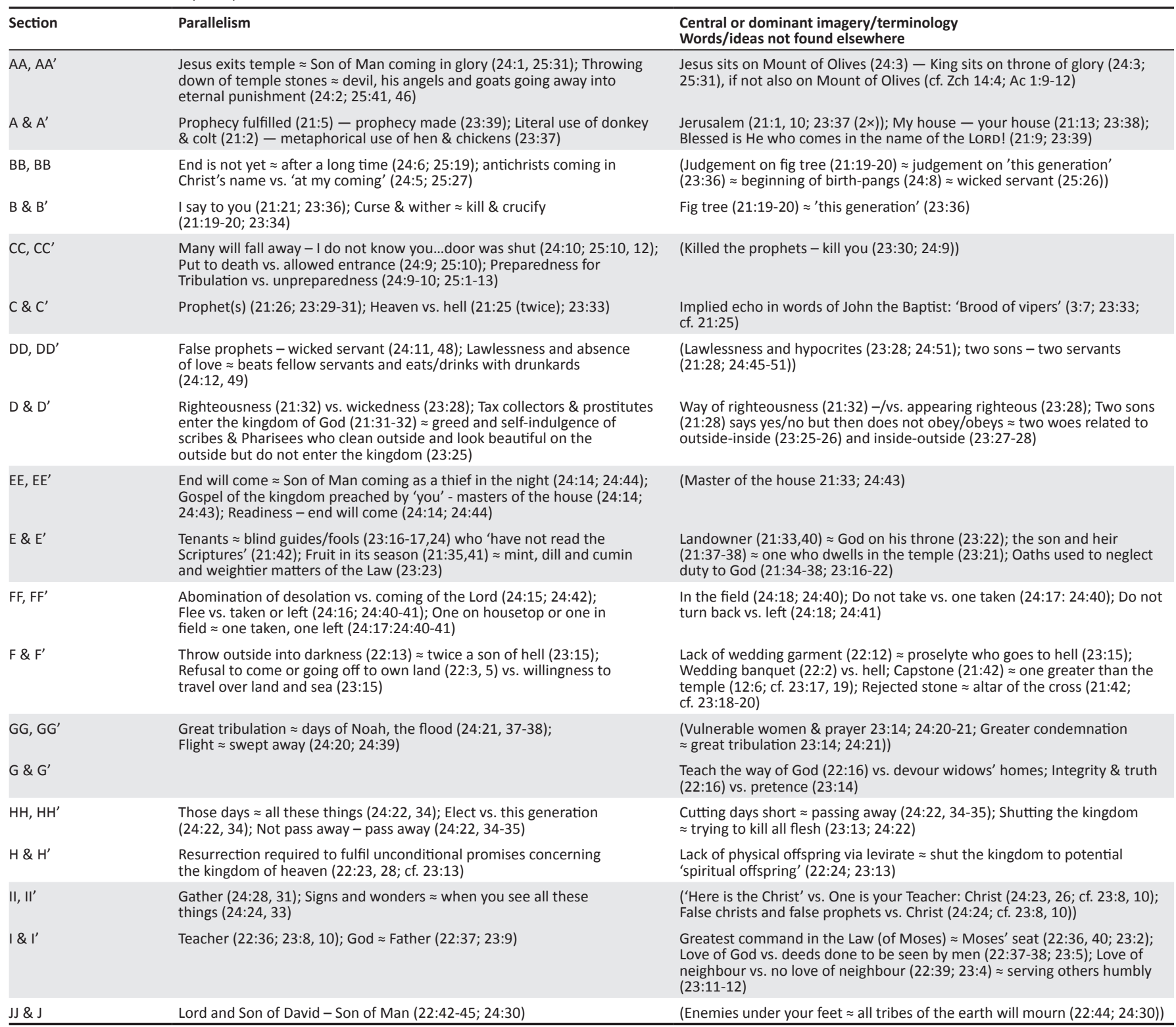

Synonymous parallelism indicated by ' - '; antithetic parallelism by 'versus' and synthetic by ' $\approx$ ' Parallelism between sections of Matthew 21:1-23:39 and 24:1-25:46 is noted in (brackets).

That the first criterion that has been met is evident, not only from the confusion over the literary role and place of Matthew 23, but also from the Matthean Olivet Discourse where the 'most difficult interpretative questions concern the structure of the discourse' (Carson 1995:491; cf. Hagner 1995:684). The following table (Table 1) shows that Blomberg's criteria 2, 3, 4 and 5 may have been met.

Criteria 6, 7 and 8 also appear to have been met, since the proposed structures have numerous corresponding sections or member sets (AA-JJ; AA'-II'; A-J; $\mathrm{A}^{\prime}-\mathrm{I}^{\prime}$ ). The centres of the structures ( $\mathrm{J}$ and $\mathrm{JJ}$ ) not only focus on the person and identity of Jesus Christ, Lord and Son of David, but also on his coming ( $\pi \alpha \rho o v \sigma i ́ \alpha, 22: 41-46 ; 24: 29-30$ ). Moreover, sections $\mathrm{A}, \mathrm{A}^{\prime}, \mathrm{AA}^{\prime}$ and $\mathrm{AA}$ all repeat the theme of the centre of these chiastic structures as highlighted in sections $\mathrm{J}$ and JJ. The proposed chiastic structures divide this literary unit into natural breaks with which most commentators agree (cf. 21:1-23:39), or at least do not disagree with (cf. 24:1-25:36). Regarding criterion 9, ruptures in the chiastic structures have been avoided. ${ }^{3}$

\section{Interpretation of Matthew 21:1-25:46}

By combining two chiastic structures that mirror each other, four corresponding pairs assist the interpretation of this complex literary unit. Since the chiastic structure of 21:1-23:39 was interpreted in a previous article in this journal (Scholtz 2014a), the discussion of the alphabetically-referenced pairs below, focuses slightly more on the interpretation of $24: 1-25: 46$ than $21: 1-23: 39$. In the discussion below, the movement is generally from the 'mirror' on the right side (21:1-23:39) to the 'mirror' on the left side (24:1-25:46).

3.If $23: 14$ is not authentic, sections $F$ and $G$ may be combined with the corresponding pair, being a combination of $G^{\prime}$ and $F^{\prime}$, and sections FF and $G G$ may likewise be combined with the corresponding pair being a combination of $\mathrm{GG}^{\prime}$ and $\mathrm{FF}^{\prime}$ 


\section{Sections $A A, A A^{\prime}, A$ and $A^{\prime}$}

As Jesus is about to exit the temple built in terms of the Davidic Covenant, he does not refer to it as 'my house' anymore, but leaves 'your house' desolate (23:38; cf. 21:5, $13 ; 24: 1)$. The next verse provides the reason ( $\gamma \alpha \dot{\alpha} \rho)$ for Jesus' statement and also indicates how long this state of affairs will continue (23:39). Because the Son of David has been rejected by 'this generation' (23:36), the temple will remain

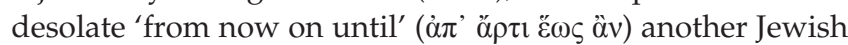
generation is willing to be gathered together, trusting that Jesus is the Messiah and praising the Coming One

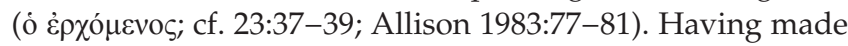
their way out of the temple and across the Kidron Valley to the Mount of Olives, the disciples ask Jesus about three things by means of two questions, 'Tell us, when will these things be? And what will be the sign of Your coming, and of the end of the age?' (24:3).

Once a future generation of Jews has trusted in Jesus and admitted that he is the Messiah (23:39; cf. 21:9), he will return to Jerusalem as King to sit on his glorious throne, acting as Judge over all the nations gathered before him (25:31-32; cf. 19:28; 24:30). The sheep inherit the kingdom but living unbelievers (goats) will not. The faith of the sheep is evidenced by their treatment of 'the least of these My brethren' $(25: 34,40)$. By serving the least of these disciples, the sheep have served the King (25:45; cf. 10:40; Carson 1995:521; Blomberg 1992:378). What connects the King to the least of his brothers and sisters is their shared willingness to obey the will of the Father $(12: 46-50 ; 25: 34)$, and the Father

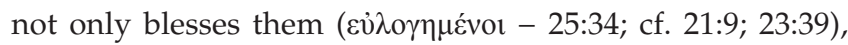
but makes them shine like the sun in the kingdom (13:43; cf. 16:27). As noted earlier, this section includes the entrance and exit of the humble Son of David (A \& $\mathrm{A}^{\prime}-21: 1-17 ; 23: 37-39$ ) as well as the prophecy of the Coming King's glorious return (AA \& $\left.\mathrm{AA}^{\prime}-24: 1-3 ; 25: 31-46\right)$.

\section{Sections BB, BB', B and B'}

The temporary movement away from Israel as a nation towards Christ's disciples from all the nations (Israel included) is evident from the day 'this generation' committed the unpardonable sin (12:23-50; cf. 13:10-17). The cursed fig tree represents 'this wicked and adulterous generation' in Israel (21:18-22; cf. Toussaint 1980:245; Constable 2014:314) on whom 'all these things' of 23:34-36 come, because they have rejected the true Christ. The inter-advent age, which includes the destruction of the temple in AD 70 and the dispersion of Jews away from the promised land and into the world, will likewise generally be characterised by the acceptance of false christs and hearing about wars and rumours of wars, but this should alarm no one, for the end is not yet (24:4-6). However, the sign that the end of the age has begun is when nation will rise against nation, and kingdom against kingdom, accompanied by famines, pestilences and earthquakes in various places - 'all these' things are the beginning of birth-pangs (24:7-8; Cooper 1983:28-32, 48; Toussaint 1980:271; Fruchtenbaum 2004:627). After noting that birth-pangs were 'in fact a common Jewish metaphor to refer to an indeterminate period of distress leading up to the end of the age (e.g., 1 Enoch 62:4; 2 Esdr 4:42; Tg. Ps 18:14)', Blomberg (1992:354; cf. Morris 1992:599) correctly adds that the events of Matthew 24:4-8 still do not justify predictions about the timing of Christ's coming (cf. 24:36; Ac 1:7). According to Cooper (1983:28-29; cf. Toussaint 1980:271), the phrase 'nation will rise against nation, and kingdom against kingdom' (cf. 2 Chr 15:1-7; Is 19:1-4) is a pure Hebraic idiom indicating a world war. After quoting the Bereshit Rabbah (XLII:4) and the Zohar Chadash to show that in Jesus' day the expression 'nation against nation, and kingdom against kingdom' referred to a world-wide conflict, Fruchtenbaum (2004:95, 626-627) concludes that World Wars I and II not only set the stage for the re-establishment of the State of Israel, but that these world wars are the sign that the end of the age has begun. ${ }^{4}$ The Church has been the primary vehicle through which the gospel of Christ is preached to the world since Pentecost. As the intensity of the birth-pangs increases, the nation of Israel comes back into focus after being dispersed from the promised land and into the world since AD 70, for this nation must trust in Jesus and admit that he is the Messiah before he will return (cf. 23:39; Hs 5:15-6:1; Zch 12:10). When the movement from Christ's disciples out of all the nations to Israel as a nation is completed, good and faithful disciples not only enter into the joy of their Master, but in the kingdom they will also exercise the various levels of authority with which Christ rewards them (25:21, 23; cf. 19:28). This section can be summarised as follows: just as the Lord judged a wicked generation (B \& B' - 21:18-22; 23:34-36), so too the Master, after his long delay, will 'settle accounts' with all his Church Age and Tribulation Period disciples, but wicked and slothful servants will be cast into the outer darkness (BB \& $\mathrm{BB}^{\prime}-24: 4-8 ; 25: 14-30$ ).

\section{Sections CC, CC', C and C'}

Having provided a sign of the beginning of the end of the age, Christ focuses on his own coming (Fruchtenbaum 2004:630). Sometime after the beginning of the birthpangs - but only God knows when - the Tribulation Period will begin and just as the scribes and Pharisees murdered the prophets in Israel, so too will saints be put to death and hated by all nations during the Tribulation for Christ's name's sake (23:30; 24:9). At that time, many will fall away and, just like others who claimed they would not have taken part in shedding the blood of prophets (23:30-31), they will betray and hate one another (24:10). Wenham (1980:158) states that $24: 10$ could refer to a great apostasy. According to Carson (1995:512), the parable of the wise and foolish virgins (25:1-13) focuses on what the kingdom 'will become like' at the 'onset of the consummated kingdom'. The proposed chiastic structures suggest that the time period covered by the parable of the wise and foolish virgins is the Tribulation Period, ending when the Bridegroom comes

4.This article does not relate $24: 4-8$ to the Tribulation Period Some futurists (c Constable 2014:353-354), however, view the entire Olivet Discourse in 24:4-25:46 Constable 2014:353-354), however, view the entire Olivet Discourse in 24:4-25:46
as related to the Tribulation Period. Even if this interpretation is true, it seems unlikely to change the proposed chiastic structure of 24:1-25:46. 
to establish the kingdom in terms of the Davidic Covenant (25:6; cf. 24:9, 29a). From a pre-tribulational perspective, Constable (2014:373; cf. Toussaint 1980:283) holds that the bride in the parable 'must be the church, the bride of Christ (cf. 2 Cor. 11:2). The church will be in heaven with Jesus, during the Tribulation, having gone there at the Rapture (1 Thess 4:13-17)'. The wise virgins, therefore, refer to disciples who became believers during the Tribulation Period (Toussaint 1980:283; Fruchtenbaum 2004:645). If the overriding theme of the parable is preparedness for the coming of the Bridegroom (cf. Hagner 1995:728; Carson 1995:512), what is the antidote to the apostasy of those times? Constable (2014:373-374) argues that, just as the Forerunner called on (Jewish) disciples to anticipate the arrival of Christ at his first coming and to be spiritually prepared for it (21:23-27; cf. 3:2; 4:17), so too during the Tribulation must disciples anticipate the Bridegroom's arrival at his $\pi \alpha \rho o v \sigma i \alpha$ - and the wise virgins will be those who repent and trust in Jesus as the Messiah at a time when the establishment of the Davidic kingdom is near. It appears that $C$ and $C^{\prime}(21: 23-27 ; 23: 29-33)$ as well as CC and $C^{\prime}$ $(24: 9-10 ; 25: 1-13)$ are chiastically linked.

\section{Sections DD, DD', D and D'}

During the Tribulation Period, many false prophets will arise and lead many astray (24:11). Just as they did at Christ's first coming, false teachers may appear outwardly beautiful, but their teaching actually gives rise to lawlessness, the very opposite of love (24:12; cf. 23:25-28). However, those who endure to the end will be delivered (24:13; cf. 10:22). Just as the parable of the two sons describes symmetrical but opposite responses at Christ's first coming, so too does the parable of the two servants show symmetrically opposite responses to the servants' responsibility during the time of the Master's delay before his second coming (21:28-32; 24:45-51). During the Tribulation, faithful and wise servants will obey the Master by giving food at the proper time (24:45; cf. 10:16-39) - a lesson applicable to the Church.

\section{Sections $E E, E E^{\prime}, E$ and $E^{\prime}$}

At Christ's first coming, the vinedressers, namely the religious leaders of 'this generation', were replaced (21:33-46; cf. Turner 2008:516). As a result of the blind guides of 'this generation' (23:16-24), the Messiahship of Jesus was rejected and the establishment of the kingdom of heaven in terms of the Davidic Covenant was postponed. These blind guides are paired antithetically with those who will be true witnesses of the gospel of the kingdom (24:14). Once the Church has completed the great commission with its focus on the gospel of Christ, the mission discourse described in Matthew 10, with its focus on the gospel of the kingdom, will be resumed (10:16-39; Scholtz 2014b:5). As a result of the appointment of new 'masters of the house', the gospel of the kingdom will be preached by Jewish messengers 'during the night' of the Tribulation Period when the establishment of the kingdom of heaven, in terms of the Davidic Covenant, is near again (24:43-44; cf. 10:16-39; 21:33-46).

\section{Sections FF, FF', $F$ and $F^{\prime}$}

Having provided a description of events or conditions during the Tribulation Period in 24:9-14, Jesus next describes in 24:15 the specific event that constitutes 'the greatest sign of all', namely the 'abomination of desolation' (Constable 2014:357; cf. Toussaint 1980:272-273; Dn 9:27; 12:11). The abomination of desolation will occur, according to Fruchtenbaum (2004:633), in two stages: firstly, the Antichrist will take over the Jewish temple, sit down in the holy of holies and declare himself to be God (2 Th 2:3-10); secondly, the false prophet will make an image of the Antichrist and set it up in the holy of holies (Dn 12:11; Rv 13:11-15). When the Beelzebub-possessed person who is 'twice a child of hell' (cf. 23:15) is revealed in the middle of the Tribulation Period (Dn 9:27; Toussaint 1980:274), those in Judea must flee to the mountains without delay: the one in the house or the field must flee without taking what is in the house or the cloak (24:16-18). ${ }^{5}$ In accordance with the proposed chiastic structure, the revelation of the Antichrist is sharply contrasted to the return of the Lord (24:40-42): one man in the field (or one woman at the mill) will be judged whereas the other will go to the wedding feast (Pettegrew 2002:187; Constable 2014:369). Those attending the wedding feast will have the required cloak of righteousness, and as described in the parable of the wedding feast, those taken in judgement do not have the wedding garment (cf. 22:1-14).

\section{Sections GG, GG', G and G'}

The woe spoken against the scribes and Pharisees for misappropriating the property of widows, doing so under cover of long pretentious prayers, all resulting in greater condemnation (23:14), is chiastically paired with the plight of pregnant women and those nursing infants in those days (24:19) - thus $G^{\prime}$ and GG in the chiastic structures. The days inaugurated by the abomination of desolation will be the worst ever - Jesus calls that time the 'great tribulation' (24:21) - and prayer should be made that 'your flight may not be in winter or on a Sabbath' (24:20). Those living in the days of Noah ignored the warnings before the flood suddenly came (24:37-39); however, once the abomination of desolation takes place, it will be absolutely crucial to heed Jesus' warnings (thus GG'; 24:36-39). Regarding the other key of this chiastic pattern, namely the question about paying taxes to Caesar (22:15-22, or G), Jesus' answer lays down the proper relationship between his people and the government (Carson 1995:460). Just as Caesar's claim to taxes is reflected in a coin that bears his image, so too should human beings made in God's image render to God what is his (cf. Constable 2014:329). As a world ruler, however, Caesar is a type that

5.The Lucan request (cf. Lk 21:7) is for a sign as to when the temple will be destroyed not for the sign of Christ's coming and the end of the age (cf. Mt 24:3). The sign of the coming destruction of Jerusalem and its temple is provided in Luke 21:20-24: the coming destruction of Jerusalem and its temple is provided in Luke 21:20-24: when you see Jerusalem surrounded by armies, then flee. Believers heeded this warning as Carson (1995:501; cf. Fruchtenbaum 2004:630) notes: '[T] here is a reasonably good tradition that Christians abandoned the city, perhaps in A.D. 68 about halfway through the siege.' Matthew 24:15-21, however, describes fleein when you see the abomination of desolation standing in the holy place. Contrary to the preterist view that 24:15-21 refers to the events of AD 70 (cf. France 2007:910), 'by the time the Romans had actually desecrated the temple in A.D. 70, it was too late for anyone in the city to flee' (Carson 1995:500). 
points to the final antitype, the Antichrist, who will not render to God the things that are God's, since he will be ruled by Beelzebub, the ruler of demons (cf. 12:24; 22:21). At that stage, paying taxes to Caesar will be equivalent to worshipping the image of the beast, as no one will then be able to buy or sell unless they have the mark or the name of the beast (cf. 22:17; Rv 13:15-18). Further, Satan's enmity towards women, who bear children created in the image of God, may then be the fiercest ever (Gn 3:15; Mt 24:19-20; cf. 22:20).

\section{Sections $\mathrm{HH}, \mathrm{HH}^{\prime}, \mathrm{H}$ and $\mathrm{H}^{\prime}$}

At Christ's first coming, the false religious leaders did not enter the kingdom themselves and also shut the doors of the kingdom to those people who wanted to enter (23:13). Similarly, close to Christ's return, if God had not determined for the elect's sake that the Great Tribulation would not be longer than three-and-a-half-years (Constable 2014:360), the satanic government of the Antichrist would physically destroy everyone on earth (24:22). Unlike 'this generation' (understood pejoratively) (Morris 1992:612-613) that will pass away once all these things have taken place, Jesus' words will not pass away (24:35). When Christ returns, many who know the Scriptures and the power of the God of the living will sit down with the resurrected Abraham, Isaac and Jacob, for he who has been given all authority in heaven and on earth will then establish the Messianic kingdom in terms of the Davidic Covenant (8:11; 22:29-32; 28:18; cf. Dn 12:2).

\section{Sections II, II', I and I'}

According to the proposed chiastic structures, false christs and prophets are contrasted with the greatest Teacher, Jesus Christ (23:1-12; 24:23-28). The true Teacher has forewarned the elect about great signs and wonders that false christs and prophets will use to deceive people (24:24-25). During the Great Tribulation, if anyone teaches 'special knowledge' (Morris 1992:607) about where Christ is (24:23, 26), do not believe it, for Christ is the believer's Teacher (23:8-10) and the coming of the Son of Man will be seen universally; it will be undeniable, unmistakable, majestic and grand (24:27; cf. Blomberg 1992:361). Just as you know that summer is approaching by noticing that the twigs of the fig tree become tender and put out leaves, so too when you see all these things, you know that the coming of the Son of Man is near, right at the door (24:32-33). In accordance with the proposed chiastic structure, 'all these things' (24:33) seem to exclude the non-signs and the beginning of 'birth-pangs' up to the Tribulation Period (24:4-8), but include everything described with regard to the Tribulation (24:9-28), especially the things in 24:23-28, which are thought to refer to the time of the Great Tribulation (cf. Toussaint 1980:278-280; Fruchtenbaum 2004:637-640). The difficult statement of 24:28 may speak of a 'final eschatological battle' (Turner 2008:579), specifically the place where, at the end of the Tribulation, Gentile nations may be gathered to move against the believing remnant of Israel. Those Jews will then trust in Jesus Christ, petitioning him to return (23:39; 24:16; Fruchtenbaum 2004:634). When
Christ returns, as the prophets foretold (cf. Is 27:12-13; Mt 22:40), the Son of Man will lovingly gather together his elect 'from the four winds, from one end of heaven to the other' (24:31; cf. Dt 30:4).

\section{Sections JJ and J}

Whereas the centre of the chiastic structure of 21:1-23:39 emphasises the authority and identity of Jesus Christ, the Lord and Son of David (22:41-46), the centre of 24:1-25:46 focuses on the sign and coming of the Son of Man (24:29-30; cf. 24:3). 'Immediately after the Tribulation of those days, the sun will be darkened, and the moon will not give its light' (24:29), but this darkness will be dispersed by the sign of the Son of Man appearing in heaven (24:30a). This sign may be the visible manifestation of God's glory followed by the coming of the Son of Man (cf. Fruchtenbaum 2004:635) or it may be the 'standard, or banner of the Son of Man' (Carson 1995:505). The Son of Man will come on the clouds of heaven with power and great glory (24:30; cf. Dn 7:13-14). At Christ's first coming, the Son of David was not recognised by many, but once the Jewish remnant petitions him to return, the Son of Man will triumphantly re-enter Jerusalem and all will behold the glory of the King $(21: 4 ; 23: 39 ; 24: 30 ; 25: 31-34$; cf. Zch 9:9).

\section{Conclusion}

Focusing exclusively on the Gospel of Matthew, the complexities of the Olivet Discourse have been addressed in two ways. Firstly, by arguing that, since Christ will not return until a Jewish generation accepts his Messiahship, the sign of his coming and the end of the age cannot appear until 'this generation' in Israel has been judged for committing the unpardonable sin. Secondly, the two mirroring chiastic structures of 21:1-25:46 may reduce the complexity in the interpretation of Matthew 24-25 and also shed light on how the parts of 21:1-23:39 and 24:1-25:46 inter-relate and correspond to each other and to this major literary unit as a whole. Only God knows when Christ will return, but until then, the Lord Jesus expects believers to watch, be ready and labour faithfully for him in these last days. When the Son of Man comes, we will behold the glory of the King.

\section{Acknowledgements Competing interests}

The author declares that he has no financial or personal relationship(s) that may have inappropriately influenced him in writing this article.

\section{References} Allison, D.C., 1983, 'Matt. 23:39-Luke 13:35b as a conditional prophecy',
Journal for the Study of the New Testament 18, 75-84. http://dx.doi.
org/10.1177/0142064X8300501803
Blaising, C.A., 2012, 'The day of the Lord and the seventieth week of Daniel',
Bibliotheca Sacra 169(674), 131-142.
Blomberg, C.L., 1989, 'The structure of 2 Corinthians 1-7', Criswell Theological Review
4(1), 3-20.
Blomberg, 1992, The New American commentary: Matthew, vol. 22, Broadman Press,
Nashville. 
Burge, G.M., 2001, 'This age, the age to come', in W.A. Elwell (ed.), Evangelical dictionary of theology, 2nd edition, pp. 1195-1196, Baker Academic, Grand Rapids.

Burrows, M., 1955, 'Thy kingdom come', Journal of Biblical Literature 74(1), 1-8. http://dx.doi.org/10.2307/3261948

Carson, D.A., 1995, The expositor's Bible commentary with the New International Version of the Holy Bible: Matthew chapters 13 through 28, Zondervan Publishing House, Grand Rapids.

Cooper, D.L., 1983, Future events revealed: An exposition of the Olivet discourse, Biblical Research Society, Los Angeles.

Constable, T.L., 2014, Notes on Matthew, 2014 edn., viewed 17 October 2014, from http://www.soniclight.com

France, R.T., 2007, The Gospel of Matthew, William B. Eerdmans Publishing Company, Grand Rapids.

Fruchtenbaum, A.G., 2004, The footsteps of the Messiah, Ariel Ministries, Tustin.

Grams, R. 1991, 'The temple conflict scene: A rhetorical analysis of Matthew 21-23', in Watson, D.F. (ed.), Persuasive artistry: Studies in New Testament rhetoric in honor of George A. Kennedy, pp. 41-65, Sheffield Academic Press, Sheffield.

Hagner, D.A., 1995, Word Biblical commentary: Matthew 14-28, vol. 33B, Thomas Nelson, Nashville.

Morris, L., 1992, The Gospel according to Matthew, William B. Eerdmans Publishing Company, Grand Rapids.
Pettegrew, L.D., 2002, 'Interpretive flaws in the Olivet discourse', The Master's Seminary Journal 13(2), 173-190.

Price, J.R., 1996, 'Jewish eschatology', in M. Couch (ed.), Dictionary of Pre-millennia Theology, pp. 103-105, Kregel Publications, Grand Rapids.

Scholtz, J.J., 2014a, 'Blessed is he who comes in the name of the LORD!' A chiastic structure for Matthew 21:1-23:39, In die Skriflig 48(1), Art. \#1802, 7 pages.

Scholtz, J.J., 2014b, 'The kingdom of heaven and Matthew 10', In die Skriflig 48(1), Art. \#1782, 8 pages.

Tasker, R.V.G., 1971, The Gospel according to St. Matthew TNTC, Eerdmans, Grand Rapids.

Toussaint, S.D., 1980, Behold the King: A study of Matthew, Kregel Publications, Grand Rapids.

Turner, D.L., 1989, 'The structure and sequence of Matthew 24:1-41: Interaction with evangelical treatments', Grace Theological Journal 10(1), 3-27.

Turner, 2008, Baker exegetical commentary on the New Testament: Matthew, Baker Academic, Grand Rapids.

Vlach, M.J., 2012, 'The kingdom of God and the millennium', The Master's Seminary Journal 23(2), 225-254.

Wenham, D., 1980, 'A note on Matthew 24:10-12', Tyndale Bulletin 31, 155-162.

Wilson, A.I., 2004, When will these things happen? A study of Jesus as judge in Matthew 21-25, Paternoster, Milton Keynes. 